\title{
Rola współpracy uczelnia-samorząd w aktywizacji przestrzeni miejskich
}

\section{The role of cooperation between the university and the local government in the activation of urban space}

\section{Streszczenie}

W artykule przedstawiono efekty współpracy samorządu gminy Zwierzyniec z uczelnią - Wydziałem Architektury Politechniki Krakowskiej. Efekty tej współpracy stanowią projekty dyplomowe inżynierskie studentów Wydziału Architektury. W publikacji omówiono problemy społeczne, gospodarcze i przestrzenno-inwestycyjne, z jakimi boryka się gmina Zwierzyniec. Jednym z podstawowych problemów omawianego terenu Roztocza jest jego „zamieranie” w sezonie jesienno-zimowym. Studenckie analizy, spostrzeżenia oraz finalne projekty mają służyć promocji Zwierzyńca i jego aktywizacji we wszystkich porach roku.

Słowa kluczowe: współpraca, uczelnia, samorząd, aktywizacja

\section{Abstract}

The paper presents the results of the cooperation of the administration of the borough of Zwierzyniec with the shool - the Faculty of Architecture of the Cracow University of Technology. The effects of this cooperation are engineer-level diploma design theses developed by students of the Faculty of Architecture. Social, economic, spatial and construction-related problems that the borough of Zwierzyniec is facing have been discussed within the publication. One of the fundamental problems that the area in question is dealing with is the "freezing" of activity in it during the autumn-winter period. The students' analyses, observations and final designs are to serve as a means of promoting Zwierzyniec and its activation throughout all the seasons of the year.

Keywords: cooperation, university, local administration, activation 


\section{WPROWADZENIE}

W 1593 roku ${ }^{1}$ utworzono na terenie Roztocza zwierzyniec myśliwski, co dało początek i nazwę miejscowości Zwierzyniec. W XIX wieku Zamoyscy przenieśli tu Zarząd Ordynacji Zamoyskiej. Na jego siedzibę przeznaczono wybudowany w tym celu kompleks klasycystycznych gmachów. Na przełomie XIX i XX wieku Zwierzyniec stał się atrakcyjną miejscowością letniskową. Urządzono wówczas park zwany ogrodem skarbowym i umieszczono w nim pomnik szarańczy, stanowiący do dziś lokalną ciekawostkę. W 1905 roku całkowicie rozebrano ogrodzenie zwierzyńca myśliwskiego. W końcu 1939 roku nadzór nad Ordynacją Zamojską przejęły władze okupacyjne, a w 1944 roku na tereny te wkroczyła Armia Czerwona. Jeszcze wówczas Ordynacja była wielkim, dobrze zorganizowanym przedsiębiorstwem ziemskim, przynoszącym niemałe dochody. 6 września 1944 roku na mocy dekretu PKWN o reformie rolnej 350-letnia Ordynacja Zamoyska została rozwiązana. W 1990 roku Zwierzyniec otrzymał prawa miejskie. To urokliwe leśne miasteczko, zwane często „perłą Roztocza” ${ }^{2}$, łączy w sobie walory naturalne - przyrodnicze i kulturowe. Cztery wieki historii Zwierzyńca zostały, na szczęście dla tego miasta, zdominowane przez Ordynację Zamojską. Za jej sprawą kulturowy rozwój tych ziem nie zniszczył, a wręcz wydobył wartości przyrodnicze, które postanowiono zachować, tworząc w 1974 roku Roztoczański Park Narodowy. Cudownie dziewicze tereny zielone, naturalne i przekształcone przez człowieka założenia wodne korespondują tu z materialnymi śladami przeszłości. W tym zakresie Zwierzyniec może być dumny z barokowego kościółka, wybudowanego na jednej z wysp stawu w latach 1741-1747, zabytkowych obiektów Zarządu Ordynacji Zamojskiej, XIX-wiecznego browaru czy wyjątkowej dzielnicy domków drewnianych o nazwie Borek. Tchnące historią, zatopioną w piękny roztoczański krajobraz, miasteczko boryka się jednak z wieloma problemami, które w większości zostały zidentyfikowane, ale czekają na rozwiązanie.

\section{PROBLEMY GMINY ZWIERZYNIEC}

W gminie Zwierzyniec zidentyfikowano główne problemy, które dotykają władze oraz mieszkańców ${ }^{3}$.

\subsection{PROBLEMY SPOŁECZNE}

W sferze społecznej wyłaniają się kwestie związane z niewystarczającą liczbą miejsc pracy dla osób z wyższym wykształceniem, niską zasobnością finansową dużej części mieszkańców, słabym wykorzystaniem instrumentów ekonomii społecznej, brakiem możliwości zapewnienia schronienia osobom i rodzinom będącym w potrzebie oraz występowaniem uciążliwości dla mieszkańców budynków wielorodzinnych o wysokiej energochłonności. Innego rodzaju zagrożenie stanowi nadmierny i uciążliwy ruch tranzytowy na przebiegającej przez miasto drodze 
wojewódzkiej i na niektórych skrzyżowaniach w Zwierzyńcu. Zaznacza się też ograniczony dostęp do rehabilitacji oraz problem z opieką nad rosnącą liczbą osób niepełnosprawnych i ludzi starszych wymagających opieki specjalistycznej. Miasto posiada niewystarczającą ofertę dotyczącą spędzania wolnego czasu, sportu, rekreacji. Nie jest należycie wykorzystany potencjał miejscowości w zakresie tworzenia oferty kulturalnej i rekreacyjno-turystycznej. Daje się też zauważyć nikłe zaangażowanie mieszkańców w mechanizmy demokracji lokalnej. Zidentyfikowano niski poziom integracji mieszkańców gminy oraz pasywność odnoszącą się do uczestnictwa w różnych wydarzeniach/inicjatywach kulturalnych, gospodarczych, społecznych, niski poziom uczestnictwa mieszkańców w zarządzaniu gminą, bardzo małą liczbę osób chętnych do działalności o charakterze wolontariatu, pasywność części korzystających z pomocy społecznej w podejmowaniu działań poprawiających ich własną sytuację materialną, niską aktywność fizyczną mieszkańców. Zauważono niewystarczającą ofertę w zakresie małej gastronomii i brak nowocześnie zorganizowanego, potrzebnego miejsca handlu bazarowego.

\subsection{PROBLEMY GOSPODARCZE}

Kluczowymi branżami, które wpływają na rozwój gospodarczy rejonu, są: przemysł drzewny (tartacznictwo, produkcja mebli, produkcja palet), gospodarka leśna, turystyka, przetwórstwo rolno-spożywcze (browar) oraz rolnictwo. Na tych polach wyłaniają się problemy dotyczące małej skali produkcji i sezonowości w tartacznictwie. Zauważone też zostały: niska pozycja konkurencyjna lokalnych Zakładów Usług Leśnych, nieuregulowany stan prawny obiektów browaru, słabo rozwinięte, rozdrobione, niskotowarowe rolnictwo, sezonowość popytu na usługi gastronomiczne. Z turystyką w rejonie związane są problemy zidentyfikowane jako brak kategoryzowanych ośrodków turystycznych, zbyt krótki sezon turystyczny, wąska, sezonowa oferta, mała liczba turystów zagranicznych, brak zintegrowanej promocji oferty turystycznej gminy. Poważne problemy dotyczą rynku pracy. Są to: mała mobilność mieszkańców, kreująca bezrobocie, niedostosowanie kwalifikacji bezrobotnych do potrzeb rynku pracy, niska aktywność części osób bezrobotnych w poszukiwaniu i podejmowaniu pracy, niewystarczające kwalifikacje zawodowe części osób świadczących usługi turystyczne. Przeszkodą w rozwoju gospodarczym gminy są też małe zasoby wolnych terenów inwestycyjnych, rozproszenie własnościowe, niewystarczająca liczba inwestorów, bardzo ograniczone możliwości pozyskania dużego inwestora oraz słabe efekty działań organizacji pozarządowych, niska aktywność organizacji pozarządowych w pozyskiwaniu środków zewnętrznych, niski poziom współpracy organizacji pozarządowych między sobą i z władzami gminy.

\subsection{PROBLEMY PRZESTRZENNO-INWESTYCYJNE (ZASOBY I POTENCJAŁ)}

W kwestii istniejących zasobów lokalowych wyłaniają się takie problemy jak: wysoka energochłonność budynków mieszkalnych, brak mieszkań socjalnych, wymagające modernizacji obiekty użyteczności publicznej, zły stan techniczny części obiektów zabytkowych. 
Stwierdzono brak kanalizacji w części gminy, konieczność budowy lokalnej sieci wodociągowej, zły stan techniczny części dróg, braki w oświetleniu, niewystarczającą ilość chodników, ścieżek rowerowych i spacerowych oraz miejsc parkingowych. W przestrzeniach publicznych istnieją bariery architektoniczne dla osób niepełnosprawnych, słabo rozwinięta jest infrastruktura turystyczna i sportowo-rekreacyjna (mało kąpielisk, brak basenu itp.). Wyłania się też wiele problemów ekologicznych: dzikie wysypiska śmieci, sukcesja wtórna na nieużytkach, zarastanie ugorów, brak lub niewystarczająco rozwinięty system kanalizacji sanitarnej, negatywne oddziaływanie szerokotorowej linii kolejowej generującej hałas i drgania, kotłownie węglowe, brak technicznych możliwości zagospodarowania odpadów organicznych, niski poziom wykorzystania odnawialnych źródeł energii, zagrożenia wynikające z intensywnego, ciężkiego ruchu tranzytowego przebiegającego przez centrum Zwierzyńca. Związane z inwestycjami problemy natury kulturowej to zanik tradycji i zwyczajów lokalnych, zbyt mała oferta imprez, wydarzeń kulturalnych, degradacja części obiektów zabytkowych, ograniczenia prawne w opiece nad obiektami zabytkowymi, nierozwiązane kwestie własnościowe.

\section{AKTYWIZACJA MIASTA. PROPOZYCJE PROJEKTOWE}

15 grudnia 2016 roku zostało zawarte porozumienie pomiędzy gminą Zwierzyniec a Wydziałem Architektury Politechniki Krakowskiej ${ }^{4}$. W ramach tego porozumienia powstało sześć inżynierskich prac dyplomowych, których autorami byli studenci siódmego semestru studiów pierwszego stopnia na krakowskim Wydziale Architektury. Studenci wraz z promotorem odwiedzili Zwierzyniec w celu wykonania wizji lokalnej oraz przeprowadzenia analiz urbanistycznych. W czasie tych wizyt mieli okazję poznać miasteczko, spenetrować zakątki, wczuć się w jego atmosferę. Spotkali się też z przedstawicielami urzędu gminy oraz społeczności lokalnej. Zapoznali się z charakterem miejsca, jego atutami, historią, kulturą, przyrodą. Przedstawiono im też problemy, z jakimi gmina się boryka i jakim musi stawić czoła. Studenci zwrócili uwagę na niski stopień uprzemysłowienia i urbanizacji Zwierzyńca i koncentracji na rolnictwie oraz leśnictwie. Zauważyli, że miasto żyje przede wszystkim w sezonie letnim, kiedy odbywają się tam imprezy kulturalne takie jak Letnia Akademia Filmowa ${ }^{5}$, Rocowisko ${ }^{6}$, warsztaty wokalne ${ }^{7}$. W zakresie oferty turystycznej organizowane są spływy kajakowe oraz przebiega tędy Szlak Rowerowy Polski Wschodniej. Zimą jednak miasto zamiera. Brakuje obiektów, które aktywizowałyby społeczność lokalną oraz wzmacniały u mieszkańców poczucie tożsamości, ale również stymulowały napływ turystów. W turystyce bowiem można upatrywać gospodarczo-społecznego rozwoju regionu, a co za tym idzie - polepszenia warunków materialnych mieszkańców. Zwierzyniec zawdzięcza swój urok przede wszystkim ogromnemu zalesieniu i pięknej przyrodzie Roztoczańskiego Parku Narodowego, jednak wiele terenów zielonych jest niezagospodarowanych i zdewastowanych. Studenci wykonali analizy: komunikacyjną, cieków wodnych, zieleni, usytuowania obiektów zabytkowych. Dokonali waloryzacji fragmentów miasta, wyciągnęli 
wnioski i opracowali wytyczne projektowe. W porozumieniu z władzami miasta zadecydowano o wykonaniu na wskazanych działkach projektów zabudowy usługowej i mieszkaniowej, która mogłaby się przyczynić do poprawy wizerunku miasta, uatrakcyjnienia go i zaktywizowania we wszystkich porach roku. Działania te wpisują się w założenia Strategicznego Planu Terytorialno-Funkcjonalnego w ramach inicjatywy "Aktywne Roztocze”.

\subsection{PRZYSTAŃ NAD ZALEWEM RUDKAํ (il. 1)}

W celu uporządkowania przestrzeni przy zachodnim brzegu zalewu Rudka na rzece Wieprz zaprojektowano przystań wraz z towarzyszącą infrastrukturą. Obecnie na działce znajduje się nieutwardzony parking.

Zaprojektowano prostą bryłę, ustawioną równolegle do linii brzegowej. Cechę charakterystyczną obiektu stanowią drewniane słupy wyeksponowane na elewacji. Nawiązują one do pni drzew rosnących w Roztoczańskim Parku Narodowym. W budynku znajduje się sala wielofunkcyjna dedykowana wydarzeniom związanym z tym miejscem. W parterze jest też hala przeznaczona na przechowywanie, naprawę i konserwację sprzętu wodnego.

Obiekt posiada podwójną fasadę szklaną. Rozciąga się więc z niego nieograniczony widok na jezioro i przyrodę Roztocza. Zastosowano tu konstrukcję szkieletową w oparciu o słupy żelbetowe.

\subsection{AMFITEATR LETNI $^{10}$ (il. 2)}

Działkę przeznaczoną na amfiteatr stanowi niezagospodarowany płaski obszar, w którego południowej części nad wodą przebiega nasyp ziemny. Teren porasta niska zieleń łęgowa.

Projekt obejmuje stworzenie koncepcji amfiteatru letniego dla ok. 800 widzów wraz z otoczeniem. Miejsce to miałoby się stać wizytówką miasta, aktywizującą lokalną społeczność i napędzającą turystykę. Odbywające się latem wydarzenia muzyczne miałyby godną i ciekawą oprawę. Muzyka byłaby słyszana zarówno z widowni, jak i z przeciwległego brzegu założenia wodnego. Bogaty program funkcjonalny zaplecza dla artystów i publiczności również stymulowałby kontakty społeczne w tym miejscu. Stworzono w tym celu lekką, „skrzydlatą" formę, w której zaproponowano użycie systemu zadaszenia z użyciem poduszek powietrznych ETFE.

\subsection{KRYTE LODOWISKO ${ }^{11}$ (il. 3)}

Działka wybrana dla projektu krytego lodowiska w Zwierzyńcu stanowi niezabudowany nieużytek w bezpośrednim sąsiedztwie Zwierzyńczyka ${ }^{12}$. Z zapisu Miejscowego Planu Zagospodarowania Przestrzennego wynika, że wszelka działalność inwestycyjna z nią związana wymaga uzgodnienia z Wojewódzkim Konserwatorem Zabytków ${ }^{13}$. 
Projekt zakłada stworzenie obiektu aktywizującego społeczność miasta żyjącego przede wszystkim latem, również w okresie zimowym. Budynek ma być magnesem przyciągającym turystów, co byłoby elementem napędzającym rozwój tego rejonu. Odpowiedzią na takie wyzwanie stał się projekt całorocznego lodowiska, wpisującego się w otaczający krajobraz. Wnętrze przenika się tu z zewnętrzem, architektura z naturą. Użytkownik lodowiska ma widok na wodę. Budynek swoim kształtem ma przypominać połamaną bryłę lodu. Wewnątrz znajdują się: hala lodowiska, zaplecze socjalno-administracyjne, widownia mogąca pomieścić ok. 200 widzów. Konstrukcja obiektu oparta jest na połączeniu żelbetu z drewnem klejonym.

\subsection{KRYTY BASEN ${ }^{14}$ (il. 4)}

Basen zlokalizowano w Zwierzyńcu przy ul. Armii Krajowej. Po przeciwnej stronie ulicy, przy której znajduje się działka, rozciąga się park. Basen będzie ogólnodostępny oraz dostosowany do potrzeb osób niepełnosprawnych. Bryła budynku jest minimalistyczna z licznymi przeszkleniami, przez które użytkownicy obiektu mogą oglądać park. Każdą elewację zdobi ażurowa konstrukcja ze stali nierdzewnej, nawiązująca formą do natury. Główną inspiracją przy tworzeniu ozdobnej okładziny budynku były drzewa i cała przyroda Roztocza. W dzień przez szczeliny między „gałęziami” elewacji wpada do wnętrza słońce, budując fantazyjne światłocieniowe kompozycje, w nocy zaś światło ze środka przenika na zewnątrz budynku, dając wrażenie leśnych prześwitów. Kolorystyka budynku utrzymana jest w tonacji szaro-biało-czarnej. Szkielet konstrukcyjny stanowią żelbetowe elementy. Nad halą basenową zaprojektowano stropodach z dźwigarów z zaimpregnowanego drewna klejonego. Gra fasad, które wyglądem przypominają gałęzie drzew, pnie czy też uwite przez ptaki gniazda, nadaje lekkości i urozmaica prostą bryłę budynku.

\subsection{BUDYNEK WIELORODZINNY Z USŁUGAMI W PARTERZE ${ }^{15}$ (il. 5)}

Obiekt ma być zlokalizowany w Zwierzyńcu w pobliżu ul. Jasnej na wąskiej działce, której otoczenie stanowią inne budynki wielorodzinne o podobnej kubaturze. Zaprojektowano czterokondygnacyjny budynek wielorodzinny z usługami w parterze. Proponowane usługi to klub fitness, zakład fryzjerski i kawiarnia. Trzy pozostałe kondygnacje zostały przeznaczone na mieszkania, które podzielono na dwa typy: jednopoziomowe o powierzchni około $70 \mathrm{~m}^{2}$ i dwupoziomowe o powierzchni około $130 \mathrm{~m}^{2}$. Mieszkania są funkcjonalne, a budynek energooszczędny.

Inspiracją dla formy była miejscowa drewniana architektura, jak również sąsiadujące otoczenie. Dla uzyskania większej lekkości bryłę rozczłonkowano, przedzielając ją szklanymi klatkami schodowymi. Użyto kolorów czarnego i białego. Aby nadać budynkowi nowoczesny, bardziej dynamiczny wygląd w charakterystyczny sposób „przekrzywiono” jego dachy. 


\subsection{HOTEL PRACOWNICZY ${ }^{16}$ (il. 6)}

Obiekt zlokalizowany ma być na działce o powierzchni $2755 \mathrm{~m}^{2}$ na zachodzie miasta przy ulicy Zdrowotnej. Inwestycja w tym miejscu wymaga uzgodnienia z Wojewódzkim Konserwatorem Zabytków ${ }^{17}$. Zaprojektowano budynek składający się z przenikających się dwóch kontrastujących ze sobą brył. Modernistyczna forma strefy wejściowej została zestawiona z klasyczną dwukondygnacyjną częścią hotelową, krytą dachem dwuspadowym. Powierzchnia zabudowy to $598 \mathrm{~m}^{2}$, a całe założenie obejmuje dodatkowo zaprojektowany na zachodzie taras, z którego roztacza się widok na pola i lasy Roztocza.

Główna bryła hotelu pokryta jest drewnianą, ażurową okładziną, która jest odsunięta od ściany i podświetlona. Ma to dać efekt lekkości i „bajkowości” w nawiązaniu do uroków „Magicznego Roztocza"18. Hotel jest dostosowany dla osób niepełnosprawnych. Zastosowane rozwiązania techniczne gwarantują energooszczędność obiektu, zaś „zielone” parkingi zapewniają odpowiednią powierzchnię terenów czynnych biologicznie. Obiekt o takiej funkcji, tak w opinii mieszkańców, jak i władz miasta, jest w tym miejscu bardzo wskazany.

\section{PODSUMOWANIE}

Zwierzyniec jest niezwykle klimatycznym, urokliwym miasteczkiem wpisującym się w naturę Roztocza. Żyje latem, zimą zaś zamiera. Będąc obserwatorem zewnętrznym, przybywającym tu na chwilę, można pomyśleć, że ta pozasezonowa ospałość Zwierzyńca jest nawet jego atutem. Przyjeżdżając z tętniących życiem miast, ze zgiełku ulic, z pędu dnia codziennego, możemy się tu wyciszyć, poobcować z przyrodą, po prostu odpocząć. Jednak ludzie odwiedzający miasteczko na dłużej w celach turystycznych zaczynają szybko szukać rozrywek i propozycji odpoczynku aktywnego. Latem te wymagania wydają się być spełnione, jakkolwiek i na ten czas można uatrakcyjnić ofertę turystyczną, dostosować ją do większej liczby odbiorców i przede wszystkim rozpropagować. Jesień, zima, a nawet i wiosna w Zwierzyńcu czekają na pobudzenie. Napływ turystów i zaktywizowanie samych mieszkańców niewątpliwie wpłynęłoby na rozwój gospodarczy miasta. Stworzone nowe miejsca pracy byłyby dostosowane do wszystkich sezonów roku. Poprawa warunków bytowych mieszkańców, ale i ich utożsamianie się z wizerunkiem atrakcyjnego turystycznie miasteczka powinno też zapobiegać odpływowi ludzi w poszukiwaniu miejsc pracy. Władze Zwierzyńca, identyfikując problemy, zwróciły uwagę na konieczność aktywizacji rejonu. Współpraca z Wydziałem Architektury Politechniki Krakowskiej polega na przygotowaniu przez studentów oferty dla miasta, obejmującej projekty architektoniczne: całorocznego lodowiska, krytego basenu, amfiteatru nad wodą, przystani nad Zalewem Rudka, hotelu pracowniczego oraz budynku wielorodzinnego z usługami w parterze. Projekty studenckie mogą stanowić element promocji Zwierzyńca, a ich realizacja niewątpliwie przyczyniłaby się do ożywienia miasta we wszystkich czterech porach roku. 


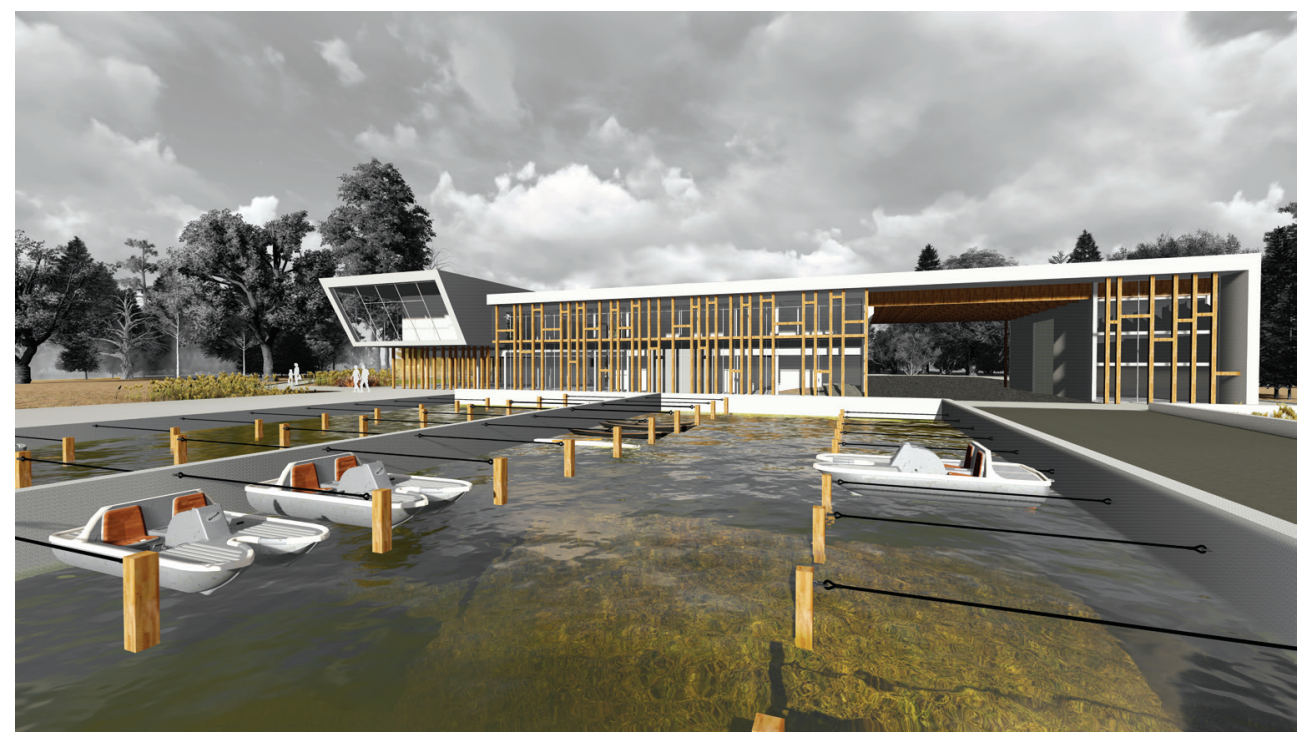

II. 1. Przystań nad Zalewem Rudka w Zwierzyńcu (Autor projektu dyplomowego: Monika Kraus, promotor: dr hab. inż. arch. Magdalena Jagiełło-Kowalczyk, prof. PK, promotor pomocniczy: dr inż. arch. Bogdan Siedlecki, Kraków 2017)

III. 1. A pier on the Rudka lake in Zwierzyniec (author: Monika Kraus)

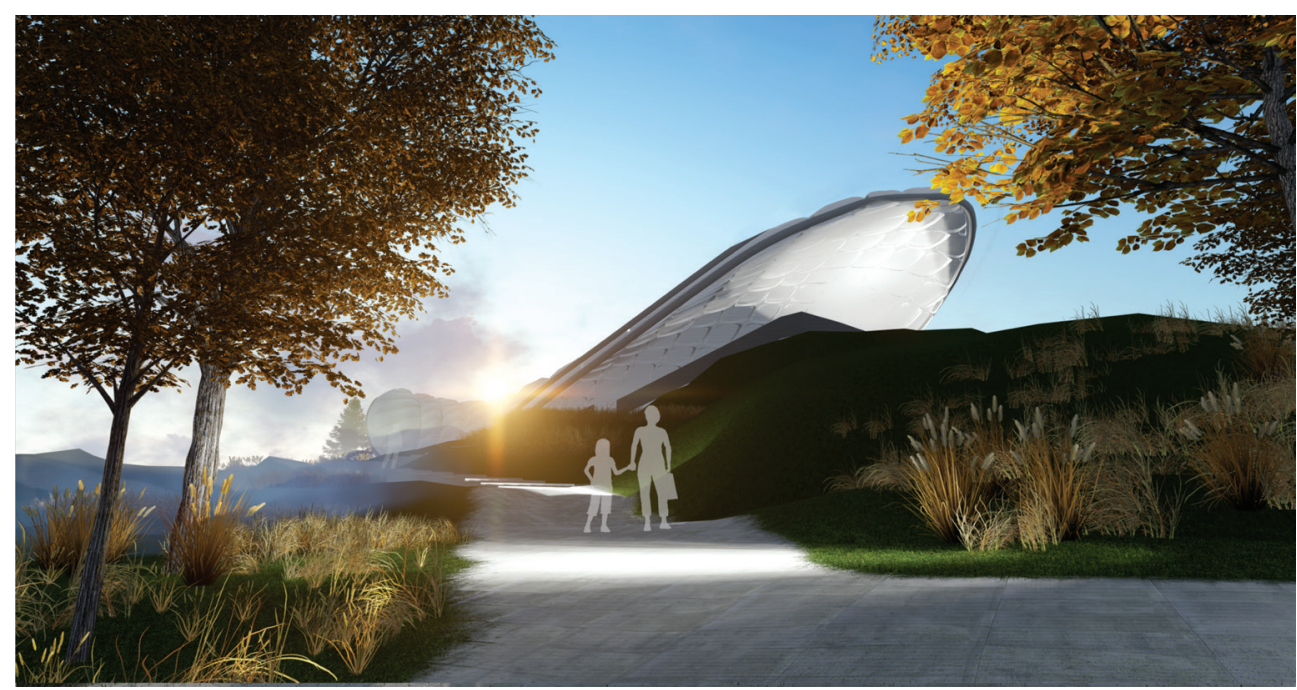

II. 2. Amfiteatr letni w Zwierzyńcu (Autor projektu dyplomowego: Joanna Skoczeń, promotor: dr hab. inż. arch. Magdalena Jagiełło-Kowalczyk, prof. PK, promotor pomocniczy: dr inż. arch. Bogdan Siedlecki, Kraków 2017)

III. 2. Summer Amphitheater in Zwierzyniec (author: Joanna Skoczeń) 


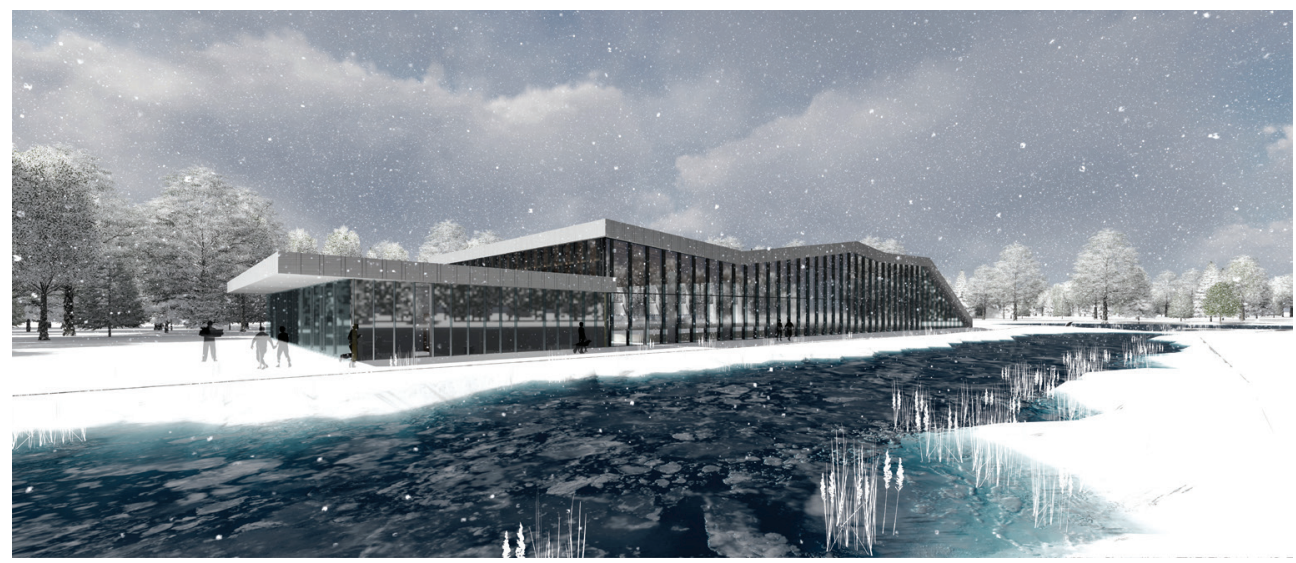

II. 3. Kryte lodowisko w Zwierzyńcu (Autor projektu dyplomowego: Konrad Piwowar, promotor: dr hab. inż. arch. Magdalena Jagiełło-Kowalczyk, prof. PK, promotor pomocniczy: dr inż. arch. Bogdan Siedlecki, Kraków 2017)

III. 3. Indoor ice rink in Zwierzyniec (author: Konrad Piwowar)

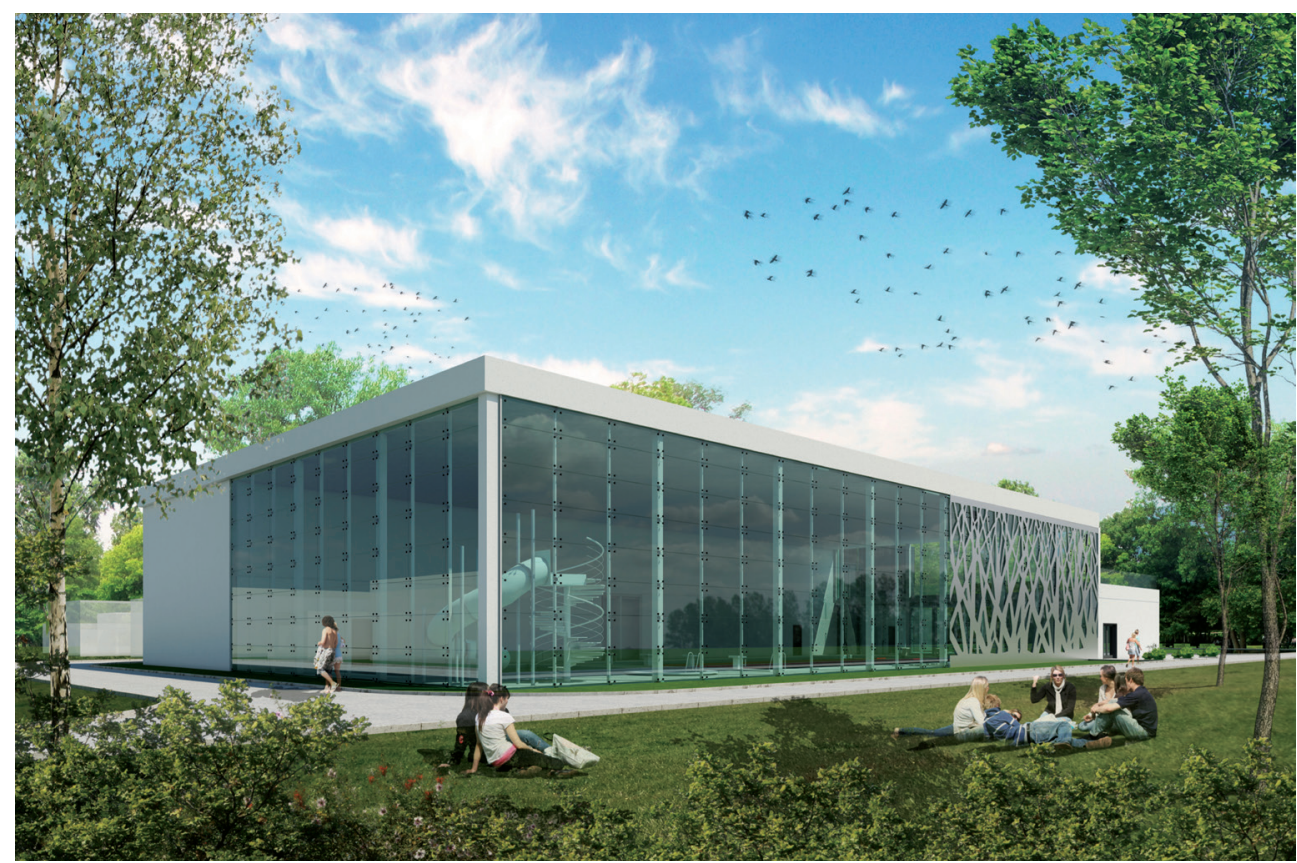

II. 4. Kryty basen w Zwierzyńcu (Autor projektu dyplomowego: Magdalena Sendor, promotor: dr hab. inż. arch. Magdalena Jagiełło-Kowalczyk, prof. PK, promotor pomocniczy: dr inż. arch. Przemysław Markiewicz, Kraków 2017) III. 4. Indoor swimming pool in Zwierzyniec (author: Magdalena Sendor) 


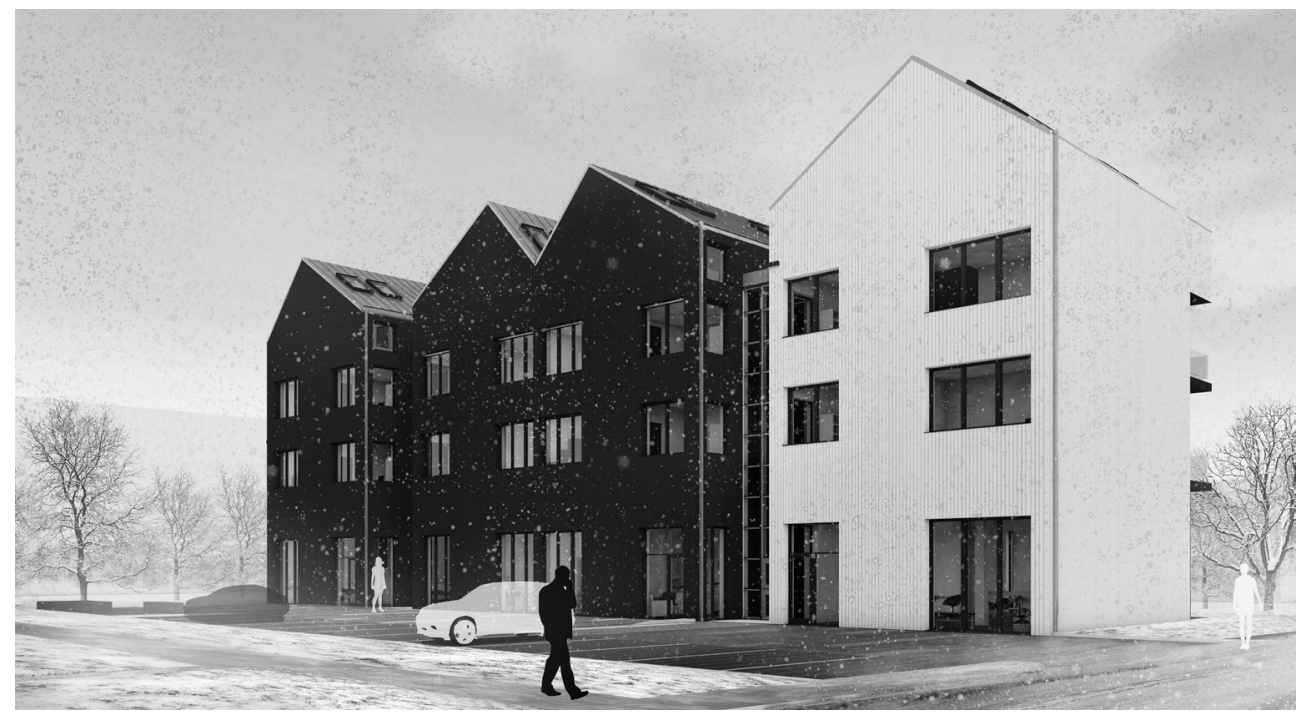

II. 5. Budynek wielorodzinny z usługami w parterze. Zwierzyniec (Autor projektu dyplomowego: Małgorzata Kozela, promotor: dr hab. inż. arch. Magdalena Jagiełło-Kowalczyk, prof. PK, promotor pomocniczy: dr inż. arch. Przemysław Markiewicz, Kraków 2017)

III. 5. Multifamily building with services on the ground floor. Zwierzyniec (author: Małgorzata Kozela)

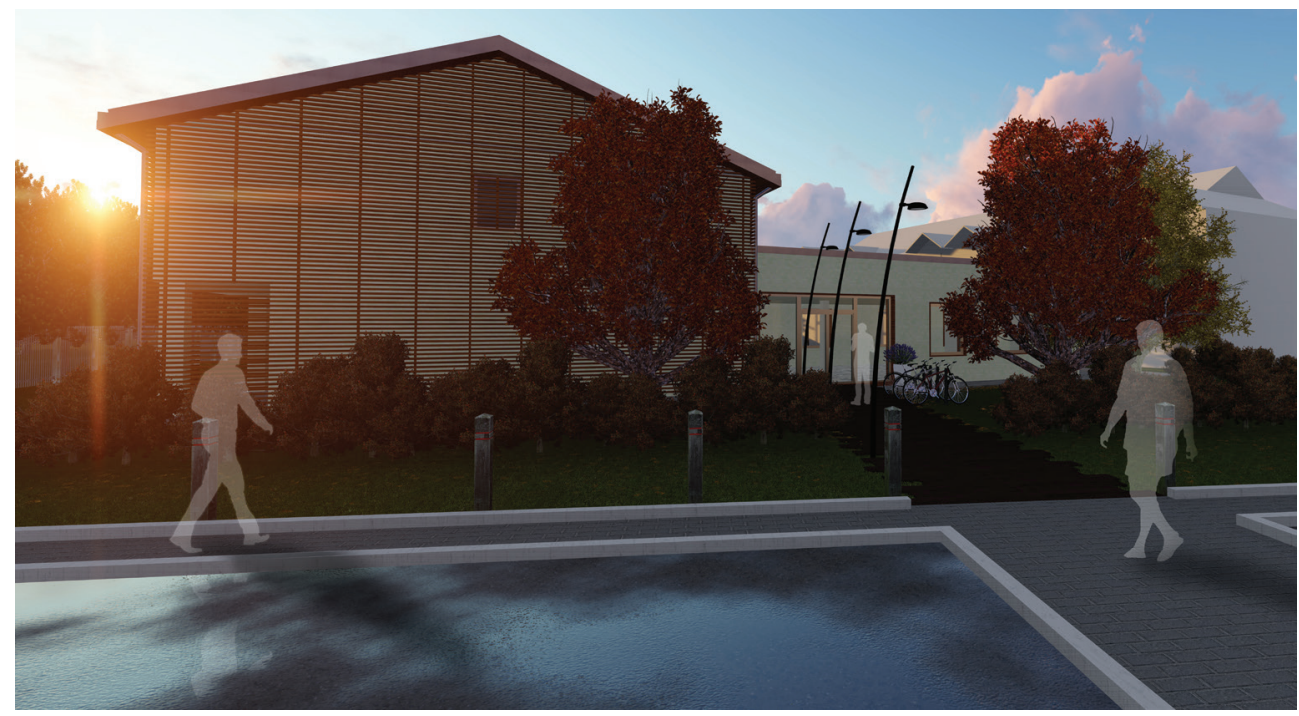

II. 6. Hotel pracowniczy w Zwierzyńcu (Autor projektu dyplomowego: Marcin Musiałek, promotor: dr hab. inż. arch. Magdalena Jagiełło-Kowalczyk, prof. PK, promotor pomocniczy: dr inż. arch. Jarosław Huebner, Kraków 2017)

III. 6. Staff hotel in Zwierzyniec (author: Marcin Musiałek) 


\section{PRZYPISY}

1 http://www.zwierzyniec.info.pl (dostęp: 17.03.2017).

2 www.magicznyzwierzyniec.pl (dostęp: 18.03.2017).

3 www.inwestycje.zwierzyniec.vipserv.org/strategia/prob.pdf (dostęp: 18.03.2017).

4 Porozumienie nr A-0/46/2016 z dnia 15.12.2016 roku o współpracy Miasta i Gminy Zwierzyniec, reprezentowanego przez burmistrza gminy Jana Skibę, z Politechniką Krakowską im. Tadeusza Kościuszki, reprezentowaną przez dziekana Wydziału Architektury prof. dr. hab. inż. arch. Jacka Gyurkovicha.

5 http://laf.net.pl (dostęp: 18.03.2017).

6 http://www.kultura-zwierzyniec.pl/rockowisko-2016 (dostęp: 18.03.2017).

7 http://www.kultura-zwierzyniec.pl/kategoria/warsztaty-wokalne (dostęp: 18.03.2017).

8 https://zwierzyniec.e-biuletyn.pl/upload/pliki/Ouchwala223.pdf (dostęp: 18.03.2017).

9 Autor projektu dyplomowego: Monika Kraus, promotor: dr hab. inż. arch. Magdalena Jagiełło-Kowalczyk, prof. PK, promotor pomocniczy: dr inż. arch. Bogdan Siedlecki, Kraków 2017.

${ }_{10}$ Autor projektu dyplomowego: Joanna Skoczeń, promotor: dr hab. inż. arch. Magdalena Jagiełło-Kowalczyk, prof. PK, promotor pomocniczy: dr inż. arch. Bogdan Siedlecki, Kraków 2017.

${ }^{11}$ Autor projektu dyplomowego: Konrad Piwowar, promotor: dr hab. inż. arch. Magdalena Jagiełło-Kowalczyk, prof. PK, promotor pomocniczy: dr inż. arch. Bogdan Siedlecki, Kraków 2017.

12 Zwierzyńczyk powstał jako projekt pt. Odtworzenie zabytkowego układu wodno-pałacowego w Zwierzyńcu wraz z zagospodarowaniem turystycznym, RPO Województwa Lubelskiego na lata 2007-2013, Oś Priorytetowa VII: Kultura, turystyka i współpraca międzyregionalna, http://www.magiczneroztocze.pl (dostęp: 29.03.2017).

${ }_{13}$ Miejscowy Planu Zagospodarowania Przestrzennego, http://www.zwierzyniec.info.pl (dostęp: 29.03.2017).

${ }^{14}$ Autor projektu dyplomowego: Magdalena Sendor, promotor: dr hab. inż. arch. Magdalena Jagiełło-Kowalczyk, prof. PK, promotor pomocniczy: dr inż. arch. Przemysław Markiewicz, Kraków 2017.

${ }^{15}$ Autor projektu dyplomowego: Małgorzata Kozela, promotor: dr hab. inż. arch. Magdalena Jagiełło-Kowalczyk, prof. PK, promotor pomocniczy: dr inż. arch. Przemysław Markiewicz, Kraków 2017.

${ }^{15}$ Autor projektu dyplomowego: Marcin Musiałek, promotor: dr hab. inż. arch. Magdalena Jagiełło-Kowalczyk, prof. PK, promotor pomocniczy: dr inż. arch. Jarosław Huebner, Kraków 2017.

${ }^{16}$ Miejscowy Planu Zagospodarowania Przestrzennego, http://www.zwierzyniec.info.pl (dostęp: 29.03.2017).

17 http://www.magiczneroztocze.pl (dostęp: 29.03.2017). 


\section{BIBLIOGRAFIA}

Kosiński W., Miasto i piękno miasta, Wydawnictwo Politechniki Krakowskiej, Kraków 2011.

Kosiński W., Paradygmat miasta 21 wieku - od polis do metropolis, Wydawnictwo Politechniki Krakowskiej, Kraków 2016.

Cabaj L., Zwierzyniec i okolice, Wydawnictwo Fotopress, Zamość 2013.

Studium uwarunkowań i kierunków zagospodarowania przestrzennego miasta i gminy Zwierzyniec. Tekst jednolity (załącznik nr 1 do Uchwały Nr LV/354/10 Rady Miejskiej w Zwierzyńcu z dnia 28 stycznia 2010 r., Burmistrz Zwierzyńca, Zwierzyniec 2009.

http://www.zwierzyniec.info.pl (dostęp: 17.03.2017).

www.magicznyzwierzyniec.pl (dostęp: 18.03.2017).

www.inwestycje.zwierzyniec.vipserv.org/strategia/prob.pdf (dostęp: 18.03.2017).

http://laf.net.pl (dostęp: 18.03.2017).

http://www.kultura-zwierzyniec.pl/rockowisko-2016 (dostęp: 18.03.2017).

http://www.kultura-zwierzyniec.pl/kategoria/warsztaty-wokalne (dostęp: 18.03.2017).

https://zwierzyniec.e-biuletyn.pl/upload/pliki/Ouchwala223.pdf (dostęp: 18.03.2017).

Miejscowy Plan Zagospodarowania Przestrzennego, http://www.zwierzyniec.info.pl (dostęp: 29.03.2017).

http://www.magiczneroztocze.pl (dostęp: 29.03.2017).

Porozumienie nr A-0/46/2016 z dnia 15.12.2016 roku o współpracy Miasta i Gminy Zwierzyniec, reprezentowanego przez burmistrza Gminy Jana Skibę, z Politechniką Krakowską im. Tadeusza Kościuszki, reprezentowaną przez dziekana Wydziału Architektury prof. dr. hab. inż. arch. Jacka Gyurkovicha. 